\title{
Ethnobotanical and ethnoecological study of Butia catarinensis Noblick \& Lorenzi: contributions to the conservation of an endangered area in southern Brazil
}

Leonardo Kumagai ${ }^{1}$ and Natalia Hanazaki ${ }^{2}$

Submitted: 27 March, 2012. Accepted: 21 August, 2012

\begin{abstract}
Butia catarinensis Noblick \& Lorenzi is a small palm (approximately $2 \mathrm{~m}$ high when full-grown) endemic to the southern coast of Brazil. Local farmers use the fruit and pulp for various purposes, and this extractive activity complements their income. The objective of this study was to understand the relationships between local people and $B$. catarinensis in its natural environment. Ethnobotanical and ethnoecological data were collected through participant observation, participatory research tools and semi-structured interviews. The density of $B$. catarinensis was measured in two areas, each containing twelve $10 \mathrm{~m} \times 20 \mathrm{~m}$ plots. Interviewees recognized different varieties of the palm, its phenological stages, as well as potential pollinators and seed dispersers. Eighteen different uses for the palm were registered and three different collection practices were observed, depending on the purpose for which the fruit was used. The mean density in the two areas studied ranged from 38.6 to 7.9 adults per plot. The rate of production (per hectare) can be as high as $927 \mathrm{~kg}$ of fruit and $190 \mathrm{~kg}$ of pulp. The local community can contribute to the conservation of this coastal ecosystem through extractive activities of some scale, with potential environmental, economic and socio-cultural sustainability.
\end{abstract}

Key words: Arecaceae, Atlantic Rainforest, ethnobotany, population ecology, coastal sand dune vegetation

\section{Introduction}

Ethnobotany and ethnoecology study the interactions between people and plants in dynamic systems, with influences of economic botany and anthropology (Alcorn 1995), and can contribute to discussions that link local human populations to areas of interest for biological conservation. These approaches take into account the interests of local communities involved in such areas in order to emphasize the importance of the traditional knowledge of the local communities, contributing not only to the recording of such knowledge but also to the promotion of their culture (Minnis 2000).

The Brazilian Atlantic Forest is one of the most threatened terrestrial biomes of the world, because of its high levels of endemism and biodiversity (Morelatto \& Haddad 2000; Scarano 2002). In the Atlantic Forest biome, one of the most threatened associated ecosystems is the restinga, or coastal sand dune vegetation, that makes up much of the Brazilian coast, which is of great interest for coastal real estate development and industrial development in natural ports (Guadagnin 1999).
Butia catarinensis Noblick \& Lorenzi is a small palm that occurs along the southern coast of Brazil, in dense clusters amid the mosaic of restinga, reaching approximately $2 \mathrm{~m}$ in height when fully grown (Reitz et al. 1978; Rosa et al. 1998; Lorenzi et al. 2010). Similar to most palms, it also has a strong relationship with the human populations that use it (Byg and Balslev 2001). It was observed in the area by the French naturalist Augustin de Saint-Hilaire and by the German traveler Robert Avé-Lallemant almost 200 years ago (Saint-Hilaire 1978; Avé-Lallemant 1980). Nowadays, the recorded uses for the fruits of the plants of the genus Butia, in southern Santa Catarina state and southern Brazil, include the production of jellies, jams, liqueurs and rum (Rosa et al. 1998; Büttow et al. 2009). However, other uses have become popular, such as using the fruit pulp for manufacturing ice cream (Büttow et al. 2009).

One location within the range of $B$. catarinensis is the community of Areais da Ribanceira, located in the municipality of Imbituba. This is an area of restinga of common agricultural use, where cassava represents the main crop and is planted in fallows. Among the cassava plantations, there

\footnotetext{
${ }^{1}$ Federal University of Santa Catarina, Department of Ecology and Zoology, Human Ecology and Ethnobotany Laboratory, Campus Trindade, Florianópolis, SC, Brazil

${ }^{2}$ Author for correspondence: natalia@ccb.ufsc.br
} 
are areas of native vegetation containing B. catarinensis. The region must be considered an area of great interest for conservation, not only for its biodiversity but also for its social relevance. The people of the community depend and maintain the use of traditional agriculture, earning a sustainable profit from this area, and play a key role in the conservation of $B$. catarinensis. The present study aims to develop a better understanding of the role of people in the conservation of this endemic palm, utilizing an ethnobotanical and ethnoecological approach. The main objective of this study was to understand the relationships between local people and B. catarinensis in its natural environment, focusing on the area of Areais da Ribanceira. Many rural communities living in areas of forest remnants rely on the extraction of plant resources as a way to augment family incomes, or even as their main source of income (Diegues 1988; Ticktin 2004). These resources can be transformed into socioeconomic products of biodiversity, considering the local cultures and traditional knowledge, which are essential for the conservation of global biodiversity (Agarwal and Narain 1992; Belcher 2003).

\section{Methods}

\section{Study Site}

The restinga of Areais da Ribanceira (28 $12^{\prime} 12^{\prime \prime} S$; $48^{\circ} 40^{\prime} 40^{\prime \prime} \mathrm{W}$ ) are located $80 \mathrm{~km}$ south of the city of Florianópolis (Fig. 1). It represents one of the major areas of restinga still preserved in the state of Santa Catarina (GERCO 2010). The restinga varies from shrub-dominated vegetation to tree-dominated forests up to $15 \mathrm{~m}$ tall, distributed over sandy soil mosaics and gradients from coastal to inland zones. Such forests are rich in shrubs and tree species belonging to the following families: Myrtaceae (Eugenia, Myrcia, Marlierea), Leguminosae (Andira), Euphorbiaceae (Croton), and Malpighiaceae (Byrsonima) (Falkenberg 1999). According to the Köppen climate classification system, the study area climate is type $\mathrm{Cfa}$, with no dry season and an average temperature above $22^{\circ} \mathrm{C}$ in the hottest month.

As described by Saint-Hilaire in 1820, subsistence activities related to the use and management of restinga and its various natural resources have been pursued in this region since the nineteenth century (Saint-Hilaire 1978). The collection of the fruit of $B$. catarinensis complements the activities of local residents who practice subsistence agriculture, especially with varieties of cassava (Manihot esculenta Crantz). People who use the common area live in five nearby neighborhoods (Aguada, Divinéia, Vila Esperança, Barranceira and Nova Brasília). The Areais area comprises a mosaic of plantation fields with dense areas of $B$. catarinensis (Fig. 1A), paleodunes with restinga vegetation on the slopes (Fig. 1B) and less dense areas with B. catarinensis in the lowlands, amidst old fallows (Fig. 1C).

\section{Data collection}

Fieldwork was carried out between May, 2009 and January, 2011, after discussing the prior informed consent with the community, which was signed by the leadership of the community and individually by some interviewees (totaling more than 20 field trips and approximately 50 days in contact with the community during this period).

Ethnobotanical and ethnoecological data were collected through participant observation, participatory research tools and semi-structured interviews (Alexiades 1996; Albuquerque et al. 2010) with open questions regarding the local knowledge of farmers. The criteria for inclusion of respondents were the practice of small-scale agriculture and whether they lived in one of five villages nearby the common area of Areais. The interviews included questions about the local names given to $B$. catarinensis, its parts, types of use in the present and past, reproductive biology (periods of flowering and fruiting), flower visitors and predation, and methods of collection. After each interview, the interviewee was asked to indicate frequent collectors or those who rely on B. catarinensis fruit collection as part of their income.

Hymenoptera listed by respondents were identified through photographs by Dr. B. C. Lopes (Federal University of Santa Catarina). Coleoptera were identified through material collected by Dr. S. A. Vanin and MSc. B. Medeiros (University of São Paulo). Mammals were identified based on their common names and regional occurrence by Dr. T.T. Castellani (Federal University of Santa Catarina). Other animals were identified based on their common names.

The density of $B$. catarinensis was measured in twelve $10 \mathrm{~m} \times 20 \mathrm{~m}$ plots in the dense areas within plantation fields (areas amidst farm fields, Fig. 1A) and in restinga area (lowlands on paleodunes, Fig. 1C), totaling 24 plots. Areas were selected according to local farmers' indications and were arranged systematically to sample the heterogeneity of the whole area. Individuals were classified as pre- and post-reproductive, based on morphological characteristics observed in the field as well as the stages proposed by $\mathrm{Da}$ Silva (unpublished data 2008) for B. capitata and Rosa et al. (1998) for B. catarinensis. Reproductive signals in each individual were observed and accounted for by the presence of floral buds (closed spadix), inflorescence with flowers, infructescences, dry inflorescence, and dry flower buds (closed and dry spadix, aborted). The productivity per individual was estimated through the counting of the number of fruits in 12 infructescences for different mother trees, and multiplied by the average weight of pulp per fruit.

Data were analyzed using descriptive statistics and through salience analysis of free listings for the categories of types of use, floral visitors, and animals that feed on $B$. catarinensis, using the software Anthropac 1.0 (Borgatti 1992). This program lists the frequency of citations (\%), the average ranking and the salience of each item cited in a free listing. The average ranking is the average position in which the informants cited such information. The salience 

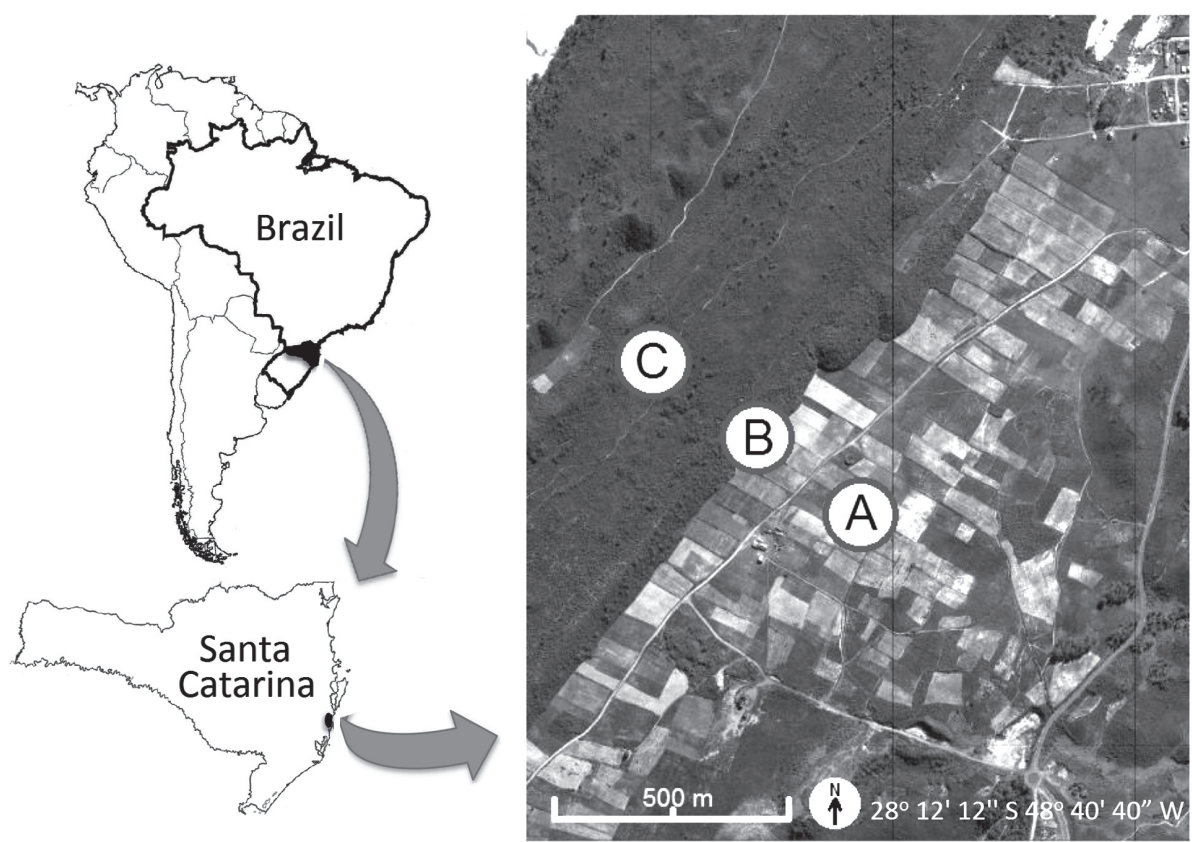

Figure 1. Imbituba, state of Santa Catarina, Brazil. Study site. A: mosaic of farm plots and areas of Butia catarinensis Noblick \& Lorenzi, B: slopes of paleodunes with restinga (sand dune vegetation); C: restinga and old fallows with B. catarinensis.

is calculated by the frequency of citation of the item and its average ranking, expressing the importance of a particular item for the studied group (Borgatti 1992). The normality of the data was tested for density of individuals between the two studied areas and compared the average values through Kruskal-Wallis analysis at $0.05 \%$ significance.

\section{Results and discussion}

The ethnobotanical and ethnoecological data resulted from 31 interviews: seven were held with a male farmer in the presence of his spouse, and the answers used was a consensus of both the farmer and his spouse, such that it was recorded as a single interview; four were conducted with female farmers; the remaining 20 interviews with the male farmers. The respondents averaged 64 years of age; the eldest was 85 and the youngest 37 years old $(n=30$; for one interviewee we did not record the age). Most of them were retirees and received a pension, which was their main source of income. There were two small grocery store owners, but small-scale farming was their main activity. Twelve respondents were born in Imbituba. Among those who were not born in the region, the average residence time was 34 years (ranging from 12 to 66 years, $\mathrm{n}=18$; information was not obtained for two informants).

The community had a general nomenclature for $B$. catarinensis and a detailed nomenclature for its parts. Farmers use the name butiá for the fruits, and butiazeiro for the entire palm. The same names are used in other parts of Brazil where other species from genus Butia occur (Rosa et al. 1998; Da Silva 2008; Büttow et al. 2009). For the closed floral spadix, they use the name buzina (literally translated as "horn"); the insertion of the youngest leaf is called the butiazeiro's eye, and the remains of the floral spadix, after the opening of the inflorescence, is called the canoe.

Respondents reported varieties of $B$. catarinensis or types that differ in fruit acidity, morphology and size. All respondents identified the sweet and sour types. For the size and pigmentation, the responses ranged between two varieties (yellow and purple or red-in 15 interviews) and up to five varieties (white, small yellow, large yellow, and red with purple to red-in 13 interviews). Five interviewees distinguished between purple and red fruits, and seven distinguished between white and yellow fruits. The type of the fruit is a characteristic of individual palm trees. The variation of colors and acidity perceived by the local farmers is similar to the variation observed by Da Silva (unpublished data 2008) with B. capitata, Büttow et al. (2009) with B. odorata and the description for palms of this genus by Lorenzi et al. (2010). According to Reitz's (1974) description, for $B$. capitata var. odorata, the color of the fruit varies, ranging from yellowish-white to yellowish. Other characteristics will also vary, such as fruit size and acidity. These results indicate that farmers from Areais recognize varieties similarly to other communities that have contact with the fruits of other species of the genus Butia. In the north of the state of Minas Gerais (Brazil), De Paula et al. (2006) found genetic variation of $B$. capitata associated with variation perceived by farmers, which may be an important aspect for investigation in future research with $B$. catarinensis. 
The ethnoecological knowledge of the interviewed farmers revealed that they are familiar with the main phenological stages of the species. According to interviewees the period of flowering is from August to April and fruiting is from October to May, with highest citations for December and February, respectively (Fig. 2). According to the farmers each palm produces three bunches per season on average (and a maximum of six), which mature at intervals of two to four weeks. According to one farmer the palms under a greater amount of sunlight produce more, because rain and heat accelerate the maturation of fruits.

The phenological calendar informed by the interviewees was longer than the one presented by Reitz (1974) and Rosa et al. (1998). One interviewee reported that the flowering and fruiting time span depend on climatic conditions, such as sun and rain intensity, similar to what Barroso et al. (2010) registered for ethnoecological knowledge of Brazilian quilombolas (members of the quilombos, communities established by freed slaves) of another palm (Euterpe edulis) in the state of São Paulo.

When asked about the animals that feed on fruits of $B$. catarinensis that are still attached to the bunch, the most salient animals were small birds and ants, but snakes were also frequent (Table 1). Less frequent but more salient than snakes and cattle were wasps, aranguá (Aves: unidentified species), mice and aracuã (Ortalis sp.) Hares, lizards, bees and wild cats were also mentioned, and in less than $10 \%$ of citations the farmers cited mosquitoes (Insecta: Diptera: Culicidae), flies (Insecta: Diptera), periá (Mammalia: Rodentia: Muridae), sabiá (Aves: Passeriformes: Turdidae), chicken (Gallus gallus domesticus), opossums (Mammalia: Didelphimorphia: Didelphidae), parrots (Aves: Psittaciformes: Psittacidae), gralha (Aves: Passeriformes: Corvidae), pampas foxes (Pseudalopex gymnocercus) and, of course, humans. Other animals feeding on the fruit of B. catarinensis still attached to the bunch or on the ground, cited at least once, were dogs, armadillos (Dasypus sp.), crab-eating foxes (Cerdocyon thous), agoutis (Dasyprocta sp.), preá (Mammalia: Rodentia), opossums, coatis (Nasua sp.), hares, lizards, snakes, ants and birds such as aranguá. Some of these animals are potential dispersers of $B$. catarinensis and the ethnoecological knowledge of farmers recognizes this: interviewee \#02 stated, "I've seen butiá gnawed on the ground, I think by rats" and interviewee \#23 reported that, "the wild cat eats butiá. I have seen the nut in their feces". Four interviewees mentioned domestic animals such as parrots, cattle and pigs, which feed on B. catarinensis fruits or nuts. As a potential predator, $90 \%$ of the interviewees cited the presence of a beetle larva called coró (Insecta: Coleoptera: Curculionidae), which feed on the seed of the palm. Other Curculionidae beetles were frequently mentioned as observed in the inflorescences, such as Anchylorhynchus tremolerasi and Liocentrinus sp.

Among the animals cited as floral visitors, the bee was the most frequent and usually was the first to be listed by respondents, which resulted in a higher salience (Table 2) when compared to the other pollinators. Even when compared to the frequency and salience of animals that feed on B. catarinensis fruits (Table 1), the bee as a floral visitor was much more salient. However, bumblebee (Insecta: Hyme-

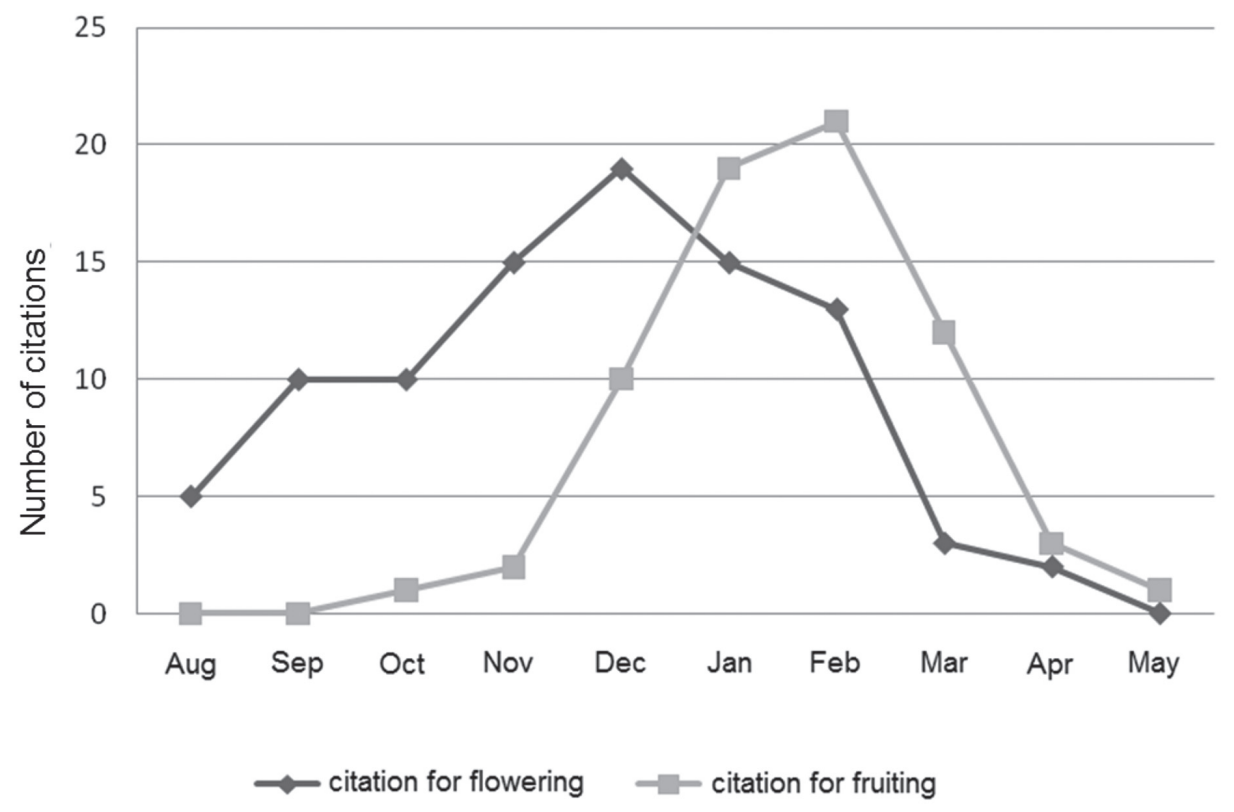

Figure 2. Ethnoecological knowledge about the phenology of Butia catarinensis Noblick \& Lorenzi: flowering and fruiting months according to 31 farmers interviewed at Areais da Ribanceira, Brazil (2009-2010). 
Table 1. Frequency of citations (\%), average rank and salience for the animals that feed on the fruit of B. catarinensis freelisted by at least $10 \%$ of the interviewees from Areais da Ribanceira, Brazil $(\mathrm{n}=20)$. Zoological identification was performed down to the most detailed taxon possible.

\begin{tabular}{lcccc}
\hline Local name (name in English) & Scientific identification & $\%$ & Rank & Salience \\
\hline Passarinho (small bird) & Aves: Passeriformes & 25 & 2.00 & 0.17 \\
Formiga (ant) & Insecta: Hymenoptera: Formicidae & 20 & 2.00 & 0.16 \\
Cobra (snake) & Reptilia: Squamata: Serpentes & 20 & 3.50 & 0.09 \\
Gado (bovine) & Mammalia: Artiodactyla: Bos taurus & 15 & 4.00 & 0.07 \\
Marimbondo (woodwasp) & Insecta: Hymenoptera: Symphyta & 15 & 1.33 \\
Aranguá & Aves: Unidentified & 15 & 1.00 & 0.12 \\
Rato (mouse) & Mammalia: Rodentia: Muridae & 15 & 1.33 & 0.15 \\
Aracuã (chachalaca) & Aves: Galliformes: Ortalis & 15 & 2.00 \\
Lebre (hare) & Mammalia: Lagomorpha: Lepus & 10 & 1.50 \\
Lagarto (lizard) & Reptilia: Squamata: Teiidae & 10 & 4.00 & 0.10 \\
Abelha (bee) & Insecta: Hymenoptera: Apidae & 10 & 1.50 \\
Gato (wild cat) & Mammalia: Carnivora: Felis & 10 & 2.50 & 0.03 \\
\hline
\end{tabular}

Table 2. Frequency of citations (\%), average rank and salience for floral visitors of B. catarinensis freelisted by at least $10 \%$ of the interviewees from Areais da Ribanceira, Brazil $(n=25)$. Zoological identification was performed down to the most detailed taxon possible.

\begin{tabular}{lcccc}
\hline Local name (name in English) & Scientific identification & $\%$ & Rank & Salience \\
\hline Abelha (bee) & Insecta: Hymenoptera: Apidae & 68 & 1.12 & 0.65 \\
Marimbondo (woodwasp) & Insecta: Hymenoptera & 36 & 2.00 & 0.19 \\
Mosca (fly) & Insecta: Diptera & 16 & 1.75 & 0.11 \\
Mamangava (bumblebee) & Insecta: Hymenoptera & 12 & 2.33 & 0.05 \\
\hline
\end{tabular}

noptera) was cited three times more and twice as often as being the most important pollinator. Other floral visitors that were cited at least once were tico-tico (Zonotrichia capensis), native bees (Insecta: Hymenoptera: Apidae), small birds, sabiás, wasps (Insecta: Hymenoptera), zongo (Insecta: Hymenoptera), hummingbirds (Aves: Apodiformes: Trochilidae), horseflies (Insecta: Diptera: Tabanidae), and butterflies (Insecta: Lepidoptera).

In a similar study involving another palm species $(E \mathcal{E}-$ terpe edulis), Barroso et al. (2010) found that most animals feeding on the palm fruit were birds and that most floral visitors were insects. For B. catarinensis, there was a higher diversity of groups both as potential predators or dispersers and as floral visitors, including birds, insects, mammals, and reptiles.

\section{Uses of Butia catarinensis}

As can be seen in Table 3, eighteen different uses for the palm or its fruits were recorded: fruits were used for juice (cited by $90 \%$ of the interviewees); rum (cited by $67 \%$ ); popsicles (cited by 47\%); in natura consumption (cited by $43 \%$ ); cocktails (cited by $17 \%$ ); ice cream (cited by $10 \%$ ); candies, desserts, and frozen slush, (cited by $7 \%$ for each); pulp (cited by $3 \%$ ); and soda pop (cited by $3 \%$ ). Leaves were used to make hats (cited by 7\%); roofs, brooms, mattresses, chair covers, and outfits (cited by $3 \%$ for each). Among the most cited uses, all of which involved the fruit itself, were juice, popsicles, rum and in natura consumption. Use for juice was mentioned in $90 \%$ of the interviews and had a high salience. For use as juice, fruits are placed in household blenders to remove the pulp from the nut, which is then strained. The amount of fruit used depends on the size and type of $B$. catarinensis. Producing one jar of juice requires approximately 20 large sweet fruits or approximately 30 fruits of the smaller, sour varieties with added sugar. Interviewee \#40 said that they prefer "very creamy juice", showing a local preference for the use of more pulp.

Butia is also used in rum, which is made when the fruit is soaked in hard liquor made from sugar cane (artisanal or industrial cachaça), which was cited by $67 \%$ of the interviews. Two respondents commented on the sale of B. catarinensis liquor in local restaurants. One respondent reported that the secret to B. catarinensis rum lies in corós (Curculionidae), which come from the fruit when submerged in the rum. In natura consumption had a slightly higher salience than butiá popsicles, indicating a slightly greater importance of the in natura consumption in the communities. Popsicles and ice cream are made by small industries in the region. Use for ice cream was mentioned by merely $10 \%$ of respondents and had low salience, despite being apparently the most significant industrial use of butiá in the region. The fruits pulp is also used for the preparation of cocktails using vodka or cachaça with sugar or condensed milk. 
Table 3. Common uses of Butia catarinensis, as cited by the interviewees.

\begin{tabular}{lccc}
\hline Uses & \% of interviewees & Rank & Salience \\
\hline Juice & 90 & 1.9 & 0.68 \\
Rum & 67 & 1.9 & 0.50 \\
Lollipops & 47 & 2.9 & 0.23 \\
Consumption in natura & 43 & 1.9 & 0.32 \\
Cocktails & 17 & 2.6 & 0.08 \\
Ice cream & 10 & 2.7 & 0.05 \\
\hline
\end{tabular}

As stated by Byg and Baslev (2001) in their study in Madagascar with the different uses of other palm species, the collection of these resources has a very clear purpose for the community, such as B. catarinensis for the farmers in the communities studied. In other words, juice, ice cream, rum and in natura consumption are the most familiar food uses, while on a small or larger scale, these have the potential to supplement income through commercialization.

Other uses mentioned by less than $10 \%$ of respondents was the use of the pulp to make jams, jellies, desserts, homemade popsicles and soft drinks. In the past, the nut was also utilized to manufacture cake flour and cocadas (coconut-based candies), after pulping and drying the fruit.

The dried leaves of the palm (collectively, the straw) are used to manufacture hats, clothes, roofs, mats and brooms. Depending on the use, straw from $B$. catarinensis goes through a greater or lesser drying time, allowing more or less flexibility to weave its fibers. According to interviewee \#14, in order to manufacture hats, "five arm lengths of strands" are required. To make straw, leaves should be collected and left to wither for three days inside the house, in the shade, and then placed to dry in the sun for three days. Six palm leaves yield three hats, which are twisted in a wooden mold.

Based on the farmers' memories, in the 1950s, the main use of this palm to cover houses with its straw, as well as manufacturing mattresses and clothing. The use of the plant for ornamental purposes was also mentioned, through the transplantation of young seedlings of $B$. catarinensis to house gardens. Three of the participants reported that when the young seedling of a butiazeiro is transplanted, it begins to yield fruit the third year after transplantation.

One of the farmers also reported the use of oil from the fruits of $B$. catarinensis for manufacturing soap, as well as the medicinal use of the roots as an anti-inflammatory. In the vicinity of Areais, there is a Pastoral da Saúde unit, which has indicated the use of $B$. catarinensis for medicinal purposes. The Pastoral da Saúde is a social institution linked to the Catholic Church, and that aims to contribute to the healthcare coordinated by to government entities responsible for the public health system.

With respect to other purposes of use, these are similar to those recorded by Büttow et al. (2009) and Büttow et al. (2010) among users of butiá in the state of Rio Grande do Sul, who describe the use of B. odorata for food and beverages, including candy, ice cream, sweets and desserts, as well as the use of the pulp (for manufacturing recycled paper) and leaf fibers for crafts (for manufacturing practical objects). Moreover, the demand for the juice could be locally driven, as occurs in the north of the state of Minas Gerais (Faria et al. 2008), where the butiá juice is a complement to school meals. Thus, the fruits of B. capitata are used as a source of fiber, provitamin $\mathrm{A}$, vitamin $\mathrm{C}$ and potassium (Faria et al. 2008). With respect to the amount of vitamin C contained in the butiá, Genovese et al. (2008) present a value of $43 \mathrm{mg} / 100 \mathrm{~g}$ of fresh weight, which is considered a significant amount of vitamin C, as previously stated by the informants in the therapeutic community of Imbituba, confirming the value of traditional knowledge practiced by the community of Areais.

\section{Extraction and management}

Farmers from Areais extract $B$. catarinensis fruits from two main places: the dense areas within the plantation fields (Fig. 1A), and the restinga/old fallow areas in the lowlands between paleodunes (Fig. 1C). The density of B. catarinensis within the plantation fields and restinga area is different (Kruskal-Wallis $\mathrm{H}=16.85, \mathrm{p}<0.0001$ ), with the plantation field areas more than three times denser than the restinga area (Table 4).

Considering the average number of adults in each area, the number of bunches per palm, and the average production per bunch of $330 \mathrm{~g} \pm 270 \mathrm{~g}$ of pulp, a general estimation of the productive potential per hectare in each of the areas was calculated (Table 4). For the dense areas within plantation fields the productive potential reaches 927 $\mathrm{kg}$ of pulp per hectare, and for the restinga area it reaches $190 \mathrm{~kg}$ of pulp per hectare. Table 4 shows the mean and standard deviation of the number of individuals of Butia catarinensis per plot in the farm plots mosaic (12 plots, 10 $\times 20 \mathrm{~m})$ and in the restinga $(12$ plots, $10 \times 20 \mathrm{~m})$, together with the productive potential per hectare.

Three different collection practices were observed. First, for immediate food consumption, the farmers collected the 
Table 4. Average and standard deviation (SD) of the number of individuals of Butia catarinensis per plot in the farm plots mosaic $(12$ plots, $10 \times 20 \mathrm{~m})$ and in the restinga $(12$ plots, $10 \times 20 \mathrm{~m})$, together with the productive potential per hectare.

\begin{tabular}{lcc}
\hline Variable & Farm plots mosaic & Restinga area \\
\hline Total number of individuals, mean (SD) & $100.2(54.9)$ & $30.7(18.8)$ \\
Number of adult individuals, mean (SD) & $38.6(14.2)$ & $7.9(6.7)$ \\
Productive potential per hectare (kg of pulp) & 927.9 & 190.4 \\
\hline
\end{tabular}

ripe fruits daily, in the fruiting season, from areas near the plantation fields, without removing the bunch from the tree. Sometimes they collected the fruits by shaking bunches over a basket; thus, the ripe fruits fall and the immature fruits remain on the palm to be harvested later. Second, for purposes of food for the family unit, the main extraction method was the cutting down of bunches - cutting the rachis of the infructescences with a machete, taking the clusters homes in baskets where the fruits were then tumbled and cleaned.

Finally, for commercial purposes, collection was performed by cutting down bunches of fruit, removing the leaflets from the rachises and bagging them while in the field. This practice was confirmed through hikes in the dunes, where many rachises from $B$. catarinensis were found accumulated on the trails. During the season, each extractor collected from $5 \mathrm{~kg}$ to $15 \mathrm{~kg}$ of $B$. catarinensis fruit daily. In their homes, extractors tumbled fruit, washed them in basins, and bagged them, taking them to the ice cream shops already sanitized. Only one of the extractors refrigerated the sanitized and bagged fruit until there was enough to sell to the ice cream shops (approximately $200 \mathrm{~kg}$ ).

Some management practices were observed. A large number of seedlings and saplings are found along the trails leading to the plantations and along the forest trails, due to the way the fruit is carried, which may indicate an unconscious dispersion by collectors. This occurs in all three forms of collection due to the use of baskets for collection or bunches of $B$. catarinensis, which are loaded on the back of the extractor, resulting in loss of ripe fruit along the walk.

A tolerance to the presence of the palm was also detected; on the trails as well as at the edges of the plantation fields the presence of young individuals and seedlings was observed. The farmers reported that for a long time these individuals were removed through the processes of weeding the land and maintenance of the trails, but today they are not withdrawn due to interest in the fruits of $B$. catarinensis.

In the area, fire has historically been utilized in agriculture for land use after fallow, and for "cleaning" the dense areas of B. catarinensis. However, because of a ban on fire use, both activities are no longer practiced. The "cleaning" of dense areas of $B$. catarinensis was for the elimination plants that grow between individuals with fire, allowing better access and mobility between butiazeiros, which may have resulted in the configuration of the dense areas within the plantation fields.
Based on the estimated collection of 5 to $15 \mathrm{~kg}$ per day by extractors and the productive potential of areas within the plantation fields and restinga, and since the fruiting peaks occur between the months of January and February, it is estimated that the maintenance of approximately 100 ha of restinga area and 2 ha of dense areas of butiá within plantation fields can provide up to $700 \mathrm{~kg}$ of fruit per day, if the use is maximized in both areas. However, it is important to highlight the maintenance of the fruit for wildlife and for the recruitment of new individuals, so these results should be interpreted with caution and only as an estimate. Reis and Kageyama (2000) argue about the importance of the fruits from the palm Euterpe edulis as a resource for wildlife in areas of Atlantic forest, and how a similar process should occur in areas of restinga for a palm such as B. catarinensis.

The three described forms of collection depend on the intended use of the extractor, being that the collection of the fruit for trade with ice cream factories corresponds to a greater quantity and more intense form of collection. In the long term and with the increased demand for ice cream, this practice may bring some environmental unsustainability to this extractive activity, as predicted by Homma (2010). The author explains that extraction alone cannot handle the increased demand of an expanding market. Similarly, the large number of seedlings and saplings along the trails may reflect the unintentional spread of the plant by the collectors. Similarly, but on different spatial and temporal scales, the indigenous people of previous centuries might have created "butiá paths" in the region of Missiones (Argentina), Paraguay, western Santa Catarina and Paraná (Rossato \& Barbieri 2007).

\section{Conclusions}

The ethnobotanical knowledge related to B. catarinensis of the community of Areais da Ribanceira of Imbituba shows the relationship that people have with this resource. The local ecological knowledge of flowering and fruiting calendars, of floral visitors and animals that feed on $\mathrm{B}$. catarinensis, shows that there is a strong relationship with the local community and this palm, not only as a food resource, but also for its ecological, cultural and ornamental values. It was evident that over time their uses have been modified according to local needs and market demands.

The extraction of natural resources like B. catarinensis provides a great potential for additional income for local 
communities. The use of other parts of the palm, e.g., the use of leaves for crafts, the use of the whole plant as ornament or the use of the nut oil, are opportunities to supplement income. These uses also add value to their production, since it makes possible the standardization of collection methods, pulping and freezing of the products within the Areais region. These activities can be stimulated through the organization of the local community, such as cooperatives. Even more important is to stimulate the maintenance of the natural range of $B$. catarinensis in the fragile areas of coastal restinga. This study shows that the local community can contribute to the conservation of restinga ecosystems. In other words, the extraction of B. catarinensis, on some scale combined with small-scale farming, is an activity with potential environmental and economic sustainability, as well as social and cultural sustainability for the local community.

\section{Acknowledgements}

This research was funded by grants from the following Brazilian agencies: the Coordenação de Aperfeiçoamento de Pessoal de Nível Superior (CAPES, Office for the Advancement of Higher Education; Grant no. PNADB 461/2010); the Fundação de Amparo à Pesquisa e Inovação do Estado de Santa Catarina (FAPESC, Santa Catarina State Foundation for the Support of Research and Innovation; Grant no. 7032/20107); and the Conselho Nacional de Desenvolvimento Científico e Tecnológico (CNPq, National Council for Scientific and Technological Development; Grant nos. 478954/2009-3 [research grant] and 306895/2009-9 [scholarship grant]). We are grateful to the local farmers, the Associação Comunitária Rural de Imbituba (ACORDI, Rural Community Association of Imbituba), I.M. Martins, E.A. Moura, F. Rivera, L.A. Cavechia, S. Zank, R.A. Poderoso, D.G. Martins and the students of the Universidade Federal de Santa Catarina (UFSC, Federal University of Santa Catarina) Graduate Program in Ecology, who assisted in the collection of data..

\section{References}

Agarwal, A. \& Narain, S. 1992. Towards a green world. New Delhi, Centre for Science and Environment.

Albuquerque, U.P., Lucena, R.F.P. \& Alencar, N.L. 2010. Métodos e técnicas para coleta de dados etnobiológicos. Pp. 40-64. In: Métodos e Técnicas na Pesquisa Etnobiológica e Etnoecológica. Albuquerque, U.P.; Lucena, R.F.P. \& Cunha, L.V.F. (Ed.) Recife: Nupeea.

Alcorn, J. The scope and aims of ethnobotany in a developing world. 1995. Pp. 23-39. In: Ethnobotany: evolution of a discipline, Schultes, R.E. \& von Reis S. (Eds.) Portland, Dioscorides Press.

Alexiades, M. 1996. Selected guidelines for ethnobotanical research: a field manual. New York, New York Botanical Garden.

Avé-Lallemant, R.C. 1980. Viagens pelas províncias de Santa Catarina, Paraná e São Paulo (1858). Belo Horizonte, Itatiaia/EDUSP.
Barroso, R.M., Reis, A. \& Hanazaki, N. 2010. Etnoecologia e etnobotânica da palmeira juçara (Euterpe edulis Martius) em comunidades quilombolas do Vale do Ribeira, São Paulo. Acta Botanica Brasilica 24: 518-528.

Belcher, M.B. 2003. What isn't a NTFP? International forestry review 5: 161-168.

Borgatti, S.P. 1992. ANTHROPAC 4.0 reference manual. Natick: Analytic Technologies.

Büttow, M.V., Barbieri, R.L., Neitzke, R.S. \& Heiden, G. 2009. Conhecimento tradicional associado ao uso de butiás (Butia spp., Arecaceae) no sul do Brasil. Revista Braseira de Fruticultura 31: 1069-1075.

Büttow, M.V., Castro, C.M., Schwartz, E., Tonietto, A. \& Barbieri, R.L. 2010. Caracterização Molecular de Populações de Butia capitata (Arecaceae) do Sul do Brasil Através de Marcadores AFLP. Revista Brasileira de Fruticultura 32: 230-239.

Byg, A. \& Balslev, H. 2001. Diversity and use of palms in Zahomena, eastern Madagascar. Biodiversity and Conservation 10: 91-97.

De Paula, T.O.M. Santos, A.M., Guilherme, D.O., Caldeira Junior, C.F., Araújo, C.B., Gonçalves, W.S., Martins, E.R. \& Lopes, P.S.N. Ecogeografia e etnobotânica do coquinho-azedo no norte de Minas Gerais. 2006. Pp. 271. In: $1^{\circ}$ Congresso Brasileiro de Fruticultura, (Org.). SBF/UENF/UFRRJ. Cabo Frio: SBF

Diegues, A.C.S. 1988. Diversidade biológica e culturas tradicionais litorâneas: o caso das comunidades caiçaras. São Paulo, NUPAUB.

Falkenberg, D.B. 1999. Aspectos da flora e da vegetação secundária da restinga de Santa Catarina, sul do Brasil. Ínsula 28: 1-30.

Faria, J.P.; Almeida, F.; da Silva, L.C.R.; Vieira, R.F. \& Agostini-Costa, T.S 2008. Caracterização da Polpa do Coquinho-Azedo (Butia capitata var. capitata). Revista Brasileira de Fruticultura 30: 827-829.

Genovese, M.I.; Pinto, M.S.; Gonçalves, A.E.S.S. \& Lajolo, F.M. 2008. Bioactive compounds and antioxidant capacity of exotic fruits and commercial frozen pulps from Brazil. Food Science and Technology International 14: 207-214.

GERCO 2010. Plano Estadual de Gerenciamento Costeiro. [WWW document]. URL http://www.spg.sc.gov.br

Guadagnin, D.L. 1999. Diagnóstico da situação e ações prioritárias para a conservação da zona costeira da região sul - Rio Grande do Sul e Santa Catarina. Porto Alegre, Pronabio.

Homma, A.K.O. O crescimento do mercado como mecanismo de desagregação da economia extrativista. 2010. Pp. 87-109. In: Etnobiologia e Etnoecologia: pessoas \& natureza na America Latina. Silva, V.A.; Almeida, A.L.S. \& Albuquerque, U.P. (Eds.). Recife, Nupeea.

Lorenzi, H.; Noblick, L.; Kahn, F. \& Ferreira, E. 2010. Flora Brasileira: Arecaceae (palmeiras). Nova Odessa, Instituto Plantarum.

Minnis, P.E. Introduction. 2000. Pp.3-10. Ethnobotany: a reader. In: Minnis, P.E.; Norman, U. (Eds.). Oklahoma.

Morellato, L.P.C. \& Haddad, C.F.B. 2000. Introduction: The Brazilian Atlantic Rainforest. Biotropica 32: 786-792.

Reis, A. \& Kageyama, P.Y. 2000. Dispersão de sementes do palmiteiro (Euterpe edulis Martius - Palmae). Sellowia (45-48): 60-92.

Reitz, P.R. 1974. Flora ilustrada Catarinense: palmeiras. Itajaí, Herbário Barbosa Rodrigues.

Reitz, R.; Klein, R.M. \& Reis, A. 1978. Projeto madeira de Santa Catarina. Sellowia 28: 58-59.

Rosa, L., Castellani, T.T. \& Reis, A. 1998. Biologia reprodutiva de Butia capitata (Martius) Beccari var. odorata (Palmae) na restinga do município de Laguna, SC. Revista Brasileira de Botânica 21: 281-287.

Rossato, M. \& Barbieri, R.L. 2007. Estudo etnobotânico de palmeiras do Rio Grande do Sul. Revista Brasileira de Agroecologia 2: 997-1000.

Saint-Hilaire, A. 1978. Viagem de Curitiba a Santa Catarina (1820). Belo Horizonte: Ed. Itatiaia/EDUSP.

Scarano, F.R. 2002. Structure, function and floristic relationships of plants communities in stressful habitats marginal to Brazilian Atlantic Rainforest. Annals of Botany 90: 517-524.

Ticktin, T. 2004. The ecological implications of harvesting non-timber Forest products - review. Journal of Applied Ecology 41: 11-21. 